NASZA DERMATOLOGIA Online OUR DERMATOLOGY Online Nil

Competing Interests: None declared

\section{THE MEN BEHIND INCONTINENTIA PIGMENTI}

\author{
Daifullah Al Aboud
}

Dermatology Department, Taif University, Taif, Saudi Arabia

Corresponding author: Dr. Daifullah Al Aboud
Incontinentia pigmenti (IP), listed in the Online Inheritance of Man (OMIM), under the number (\#308300), is an $\mathrm{x}$-linked dominant condition that affects skin, teeth, eyes and may also have neurological problems. The IP name describes the histological characteristics, the incontinence of melanin into the melanocytes cells in the epidermal basal layer and its presence in superficial dermis [1,2].

Garrod reported the first probable case of incontinentia pigmenti in 1906 and described it as a peculiar pigmentation of the skin in an infant with mental deficiency and tetraplegia. Subsequently, Bloch and Sulzberger further defined the condition in 1926 and 1928, respectively, as a clinical syndrome. Hermann Werner Siemens (1891-1969), is a German dermatologist, who also, contributed to the description of this disease and his name is also linked to the eponyms of this disease.

IP is caused by mutations in the NEMO (NF- $\mathrm{kB}$ essential modulator) gene, the protein product of which protects against tumor necrosis factor- $\alpha$-induced apoptosis.

Between 900 and 1,200 affected individuals have been reported in the scientific literature. Most of these individuals are female.

Cutaneous findings are the most common manifestation of IP and usually represent the presenting signs. They are divided into four overlapping stages: (1) vesiculobullous, which favors the extremities during the first few months of life (but occasionally recurs during childhood in association with a febrile illness); (2) verrucous, which favors the distal extremities in patients one to six months of age (and sometimes adolescents); (3) hyperpigmented, which favors the trunk and intertriginous sites from three months of age through adolescence; and (4) hypopigmented/atrophic, which affects the calves in adolescents and adults [1,2].

The extracutaneous manifestations of IP, which are less frequent than are the skin findings, are more likely to cause morbidity. These include dental abnormalities (such as small teeth or few teeth), eye abnormalities that can lead to vision loss, and central nervous system (CNS) abnormalities also occur in one-third of IP patients and can include seizures, developmental delay, and spastic paresis. However, most people with incontinentia pigmenti have normal intelligence. Infants with IP should be referred to a pediatric ophthalmologist for evaluation and close follow-up. In addition, neurodevelopmental status should be monitored, and a pediatric neurologist consulted if problems arise [1,2]. Early dental intervention is also recommended.

Incontinentia Pigmenti International foundation (IPIF) is a voluntary nonprofit organization founded in 1995. Its mission is to encourage and support research on IP, and to provide family support and education. Further details about this organization can be seen at its official website, http:// www.ipif.org/

There are several synonyms for IP. These includes BlochSiemens syndrome, Bloch-Sulzberger disease, BlochSulzberger syndrome, Bloch-Siemens-Sulzberger Syndrome, melanoblastosis cutis, melanoblastosis cutis linearis, nevus pigmentosus systematicus, and pigmented dermatosis, Siemens-Bloch type.

However, Bloch-Sulzberger syndrome, is the most common eponym for this disorder, I am going to highlight on the dermatologists behind this eponym.

\section{Bruno Bloch (1878- 1933)}

Bruno Bloch is, a Swiss dermatologist [3-5] (Fig. 1). He graduated from the University of Basel in 1900 and obtained his doctorate in 1902. He received further education at the medical and dermatological clinic in Basel, as well as in Vienna under Gustav Riehl (1855-1943), Berlin, Paris, and in Bern under Josef Jadassohn. In 1908 he was appointed as head of dermatology at the University of Basel, where he was habilitated for dermatology and syphilology in 1909. In 1916 he was called to the newly established chair of dermatology at the University of Zurich, where he remained until his death in 1933 [3].

Bloch founded the collection of moulages at the Department of Dermatology, Zürich University Hospital. This collection is still well preserved and offers the possibility of following Bloch's scientific interests [4]. 
To mark the occasion of the 75th anniversary of Bruno Bloch's appointment to the Chair of Dermatology in Zurich, a commemorative lecture was established. The speaker paid tribute to his professional achievements and to the careers of some of his followers (Wilhelm Lutz, Basel; Marion B. Sulzberger, New York; Edwin Ramel, Lausanne; Hubert Jäger, Lausanne; Werner Jadassohn, Geneva; Guido Miescher, Zurich) [5].

\section{Marion Baldur Sulzberger (1895-1983)}

Marion Baldur Sulzberger, was one of the most famous American dermatologists [6,7] (Fig. 2). He had received his training in dermatology in Zurich (Switzerland) from 1926 to 1929 . The collection of moulages in Zurich still preserves outstanding wax models of Sulzberger's scientific work. They are impressive examples of the purpose and value of

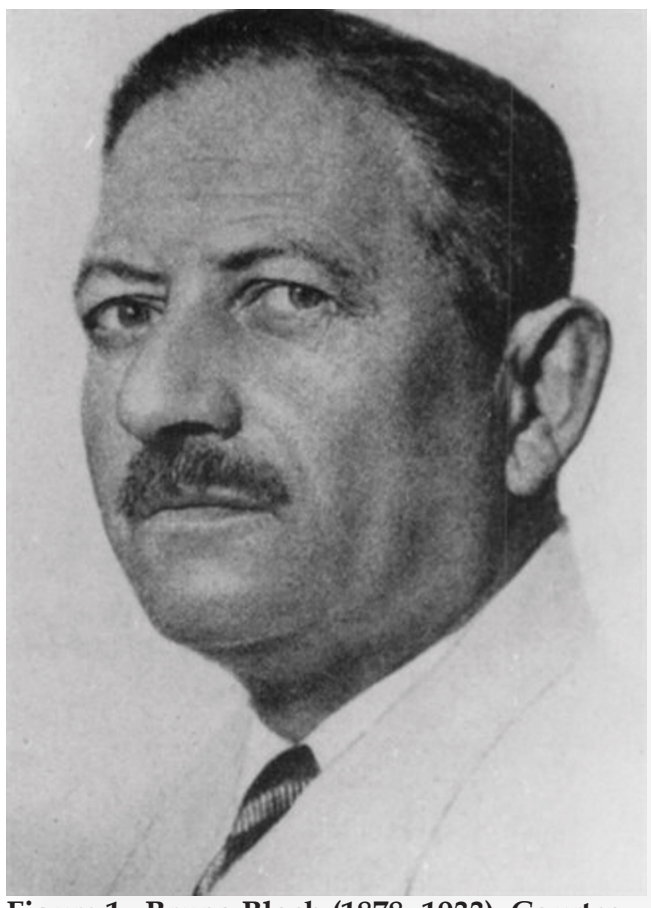

Figure 1. Bruno Bloch (1878- 1933). Courtesy, Dermatologisches Zentrum Berlin moulages at the beginning of the 20th century being used as teaching aids but also as documents and illustrations in scientific articles and textbooks [6].

He began his medical studies in Geneva, Switzerland, in 1920, but later changed to the University of Zurich. During this period he came into contact with Josef Jadassohn (1863-1936), professor of dermatology in Bern, and Bruno Bloch (1878-1933), who had been appointed to the chair of dermatology at Zurich in 1916 [7].

When he returned to America. He entered private practice with Fred Wise (1881-1950) [7].

In 1949 Sulzberger became professor of dermatology and syphilology of the New York University-Bellevue Medical Center. He retired from the chair of dermatology in 1961, but three years later he accepted an appointment as professor of clinical dermatology at the University of California in San Francisco. He retired from his tenure in 1970 [7].

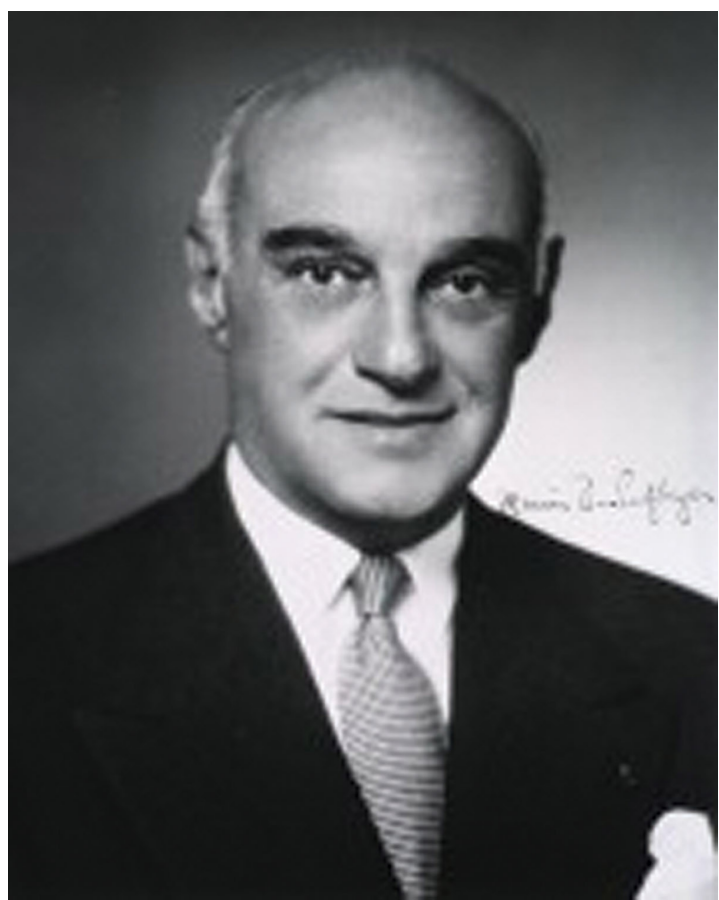

Figure 2. Marion Baldur Sulzberger (1895-1983). Courtesy, National Library of Medicine

\section{REFERENCES}

1. Jabbari A, Ralston J, Schaffer JV: Incontinentia pigmenti. Dermatol Online J. 2010;16:9.

2. Arenas-Sordo Mde L, Vallejo-Vega B, Hernández-Zamora E, Gálvez-Rosas A, Montoya-Pérez LA: Incontinentia pigmenti (IP2): familiar case report with affected men. Literature review. Med Oral Patol Oral Cir Bucal. 2005;10Suppl 2:E122-9.

3. Bruno Bloch: A page in the internet.Whonamed it. (C) 1994 - 2012 Ole Daniel Enersen. Available online at; http://www.whonamedit. com/doctor.cfm/1200.html
4. Rüdlinger R, Stoiber E: [The Bloch era as reflected in the moulages collection at the Zurich Dermatological University Clinic 1917-1933]. Hautarzt. 1988;39:314-7.

5. Schnyder UW: [Bruno Bloch and his students. 1. Bruno Block memorial lecture, 8 November 1991, Zurich]. Hautarzt. 1993;44:324-7.

6. Marion Baldur Sulzberger: A page in the internet.Whonamed it. (C) 1994 - 2012 Ole Daniel Enersen. Available online at; http://www. whonamedit.com/doctor.cfm/1660.html

7. Geiges ML: Traces of Marion B. Sulzberger in the Museum of Wax Moulages in Zurich and their importance for the history of dermatology. J Am Acad Dermatol. 2009;60:980-4.

Copyright by Daifullah Al Aboud. This is an open access article distributed under the terms of the Creative Commons Attribution License, which permits unrestricted use, distribution, and reproduction in any medium, provided the original author and source are credited. 